\title{
Acetobacterium, a New Genus of Hydrogen-Oxidizing, Carbon Dioxide-Reducing, Anaerobic Bacteria
}

\author{
WILLIAM E. BALCH, S. SCHOBERTH, † RALPH S. TANNER, AND R. S. WOLFE \\ Department of Microbiology, University of Illinois, Urbana, Illinois 61801
}

\begin{abstract}
A new genus of fastidiously anaerobic bacteria which produce a homoacetic fermentation is described. Cells are gram-positive, oval-shaped, short rods which are actively motile by means of one or two subterminal flagella. Hydrogen is oxidized, and carbon dioxide is reduced to acetic acid. Organic substrates which are fermented in a mineral medium include fructose, glucose, lactate, glycerate, and formate. Pantothenate is required as a growth factor. The deoxyribonucleic acid base composition of the type species is $39 \mathrm{~mol} \%$ guanine plus cytosine. The name Acetobacterium is proposed for this new genus, which is tentatively placed in the family Propionibacteriaceae. The type species, Acetobacterium woodii sp. nov., is named in honor of Harland G. Wood. The type strain of $A$. woodii is WB1 (= ATCC 29683 and DSM 1030).
\end{abstract}

Homoacetic fermentations of carbohydrate by anaerobic bacteria are rare. For a number of years, Wood and his associates studied the total synthesis of acetate from carbon dioxide in the homoacetic fermentation of glucose by Clostridium thermoaceticum $(5,8,14,15)$. Results of recent work indicate that in the $1 \mathrm{~mol}$ of acetate which is synthesized from 2 mol of carbon dioxide by this organism, the carboxyl group of pyruvate rather than free carbon dioxide is the precursor of the carboxyl group of acetate by a transcarboxylation reaction (14). Clostridium formicoaceticum likewise produces a homoacetic fermentation of fructose $(1,11)$. These organisms require reduced organic compounds as substrates, and neither organism produces nor uses molecular hydrogen.

The oxidation of hydrogen and the reduction of carbon dioxide to acetic acid by a stabilized enrichment culture were reported in 1932 (6); a few years later, the isolation of Clostridium aceticum was accomplished by Wieringa $(16,17)$. This organism produced acetic acid from hydrogen and carbon dioxide as well as from carbohydrates. Unfortunately, C. aceticum was lost soon after the third paper on this anaerobe was published in 1948 (7). Repeated attempts to reisolate it in various laboratories over the past 25 years have failed.

We report here the isolation of an organism which produces a homoacetic fermentation and which grows by the anaerobic oxidation of hydrogen and reduction of carbon dioxide according to the following equation:

$\dagger$ Present address: Institut für Mikrobiologie der Universität, D-3400 Göttingen, Federal Republic of Germany.
$4 \mathrm{H}_{2}+2 \mathrm{HCO}_{3}^{-}+\mathrm{H}^{+} \rightarrow \mathrm{CH}_{3} \mathrm{COO}^{-}+4 \mathrm{H}_{2} \mathrm{O}$

The $\Delta \mathrm{G}_{0}^{\prime}$ of this reaction is -25.6 (4). To our knowledge, this is the first organism to be isolated, since the loss of $C$. aceticum, which is capable of reducing carbon dioxide to acetic acid by the use of molecular hydrogen. A brief report on this organism has appeared previously ( $\mathrm{S}$. M. Schoberth and W. E. Balch, Abstr. Annu. Meet. Am. Soc. Microbiol. 1975, I90, p. 131).

\section{MATERIALS AND METHODS}

Bacterial strains. Strain WBI of the acetogenic organism was isolated from black sediment of Oyster Pond Inlet, a marine estuary, Woods Hole, Mass. Strains RT1 and RT2 were obtained from black sediments of Crystal Lake, Urbana, Ill.

Media. Sterile media for the isolation, subculture, and maintenance of organisms were prepared by techniques recently described (2). Basal medium (M1) contained (in grams per liter of distilled water): $\mathrm{NH}_{4} \mathrm{Cl}$, $1.0 ; \mathrm{MgSO}_{4} \cdot 7 \mathrm{H}_{2} \mathrm{O}, 0.1 ; \mathrm{K}_{2} \mathrm{HPO}_{4}, 0.4 ; \mathrm{KH}_{2} \mathrm{PO}_{4}, 0.4$; resazurin, 0.0001 ; cysteine $\cdot \mathrm{HCl}, 0.5 ; \mathrm{Na}_{2} \mathrm{~S} \cdot 9 \mathrm{H}_{2} \mathrm{O}, 0.5$; $\mathrm{NaHCO}_{3}, 2.0$. Vitamin solution and mineral solution (18) were each added in $10-\mathrm{ml}$ amounts to 1 liter of medium. The final $\mathrm{pH}$ of the medium, after sparging with nitrogen or hydrogen which contained $20 \%$ carbon dioxide, was 6.7. When medium $\mathrm{M} 1$ was incubated in a pressurized atmosphere of $\mathrm{H}_{2}-\mathrm{CO}_{2}(67: 33)$ of 2 atm, $\mathrm{NaHCO}_{3}$ was added at a concentration of $7 \mathrm{~g}$ per liter. Solid medium (M2) for plates was prepared by the addition of the following compounds (grams per liter) to medium M1: Noble agar (Difco), 20.0; $\mathrm{CaCO}_{3}, 10.0$; and yeast extract (Difco), 2.0. Plates were poured and streaked in an anaerobic chamber and were then incubated under a gas mixture of $\mathrm{H}_{2}-\mathrm{CO}_{2}$ (67:33) at a pressure of $2 \mathrm{~atm}$ by the use of techniques which we have recently described in detail (2). Organic substrates (see Table 1) were added at a final concen- 
tration of $0.5 \%(\mathrm{wt} / \mathrm{vol})$ to either medium M1 or M2 as desired.

Methods. Growth of the organism in each culture tube (optical path $18 \mathrm{~mm}$ ) was followed by measuring the absorbancy in a Bausch and Lomb spectrophotometer model 20 at $660 \mathrm{~nm}$. Gas consumption by the organism was determined by measurement at appropriate intervals during growth of the pressure inside each culture tube (2). Cells were mass-cultured in fermentors by techniques reported previously (3); the fermentor contained a $\mathrm{pH}$ electrode, and sterile $\mathrm{NaOH}$ was automatically added to maintain the $\mathrm{pH}$ at 6.7 . The production of acetate was determined by the acetate kinase method (12), and the utilization of fructose was determined by the method of Nelson (10). A Packard gas chromatograph equipped with a Poropak Q100-120 mesh column and an electron-capture detector was used to quantitate hydrogen and carbon dioxide.

To study the stoichiometry of $\mathrm{H}_{2}$ oxidation and $\mathrm{CO}_{2}$ reduction to acetic acid, growth of cultures was followed in sealed tubes in medium M1. Each tube was pressurized to $2 \mathrm{~atm}$ with a mixture of $\mathrm{H}_{2}-\mathrm{CO}_{2}$ (67:33). An inoculum which represented $2 \%$ of the medium volume was added to tubes in which growth was to be followed; uninoculated tubes served as controls to determine possible gas loss through leakage during sampling. At each time period, a 100- $\mu$ l sample of medium was removed with a syringe and was assayed for acetate. The gas pressure in each tube was measured, and gas consumption was calculated (2). Acetic acid which was formed during growth was neutralized by injection of sterile $0.5 \mathrm{M} \mathrm{NaOH}$.

For the determination of the vitamin requirements of the acetogenic organism, medium M1 was prepared without the addition of the vitamin solution, and $\mathrm{NaHCO}_{3}$ (7 g/liter) was added. A 5-ml amount of medium was placed in each tube, and sealed tubes were pressurized to $2 \mathrm{~atm}$ with a gas mixture of $\mathrm{H}_{2}$ $\mathrm{CO}_{2}(67: 33)$.

For isolation of deoxyribonucleic acid (DNA), cells were suspended at a concentration of $0.4 \mathrm{~g} / \mathrm{ml}$ in 0.2 $\mathrm{M}$ ethylenediaminetetraacetate $(\mathrm{pH} 8)$ which contained $0.075 \mathrm{M} \mathrm{NaCl}$ and were passed through a French pressure cell at $3,000 \mathrm{lb} / \mathrm{in}^{2}$. Sodium dodecyl sulfate was added to the cell lysate at a final concentration of $2 \%$, and the DNA was purified from the lysate by the method of Marmur (9) with the following modifications: (i) the lysate was incubated at $37^{\circ} \mathrm{C}$ overnight with $3 \mathrm{mg}$ of Pronase (Calbiochem, La Jolla, California) per $\mathrm{ml}$ prior to the addition of sodium perchlorate; (ii) after the pancreatic ribonuclease digestion of the DNA preparation, the digest was deproteinized using water-saturated phenol. The buoyant density of the DNA was determined by a cesium chloride density gradient centrifugation in a Beckman model $\mathrm{E}$ ultracentrifuge. The moles percent guanine plus cytosine $(\mathrm{G}+\mathrm{C})$ was calculated by the method of Schildkraudt et al. (13). DNA from Micrococcus luteus was used as a standard.

For electron microscopy, cells were negatively stained with a $3 \%$ aqueous solution of uranyl acetate, pH 4.8. Micrographs were taken with a Philips EM 301 microscope.

\section{RESULTS}

Development of enrichment-culture techniques. In the studies reported here, evidence for hydrogen-oxidizing acetogenic bacteria was first observed in an enrichment culture for hydrogen-oxidizing methanogenic bacteria. The culture was initiated by inoculation of $0.5 \mathrm{ml}$ of black lake sediment into $8 \mathrm{ml}$ of medium M1 in a tube $(18$ by $150 \mathrm{~mm})$ fitted with a solid black rubber stopper pierced by two 20-gauge hypodermic needles, one of which reached to the bottom of the tube and the other of which, being only $2 \mathrm{~cm}$ long, did not. A mixture of $\mathrm{H}_{2}-\mathrm{CO}_{2}$ $(80: 20)$ was passed through the longer needle at a rate of about $0.5 \mathrm{~cm}^{3} / \mathrm{min}$, and the effluent was vented through tubing from the short needle so that it bubbled through water in an open tube. To insure a more efficient use of gases, several tubes were connected in series by polyethylene tubing so that the effluent of one tube became the influent for the next. After 3 weeks of continuous bubbling at room temperature, no methane was detected in the effluent, but acetic acid was readily detectable. The black rubber stoppers were swollen and deformed, exhibiting the typical response of such stoppers when they are exposed to vapors of acetic acid. The turbidity of the medium was negligible, and we were amazed that such a small biomass could produce acetic acid in an amount sufficient to produce the above-mentioned results.

With black sediment from a marine estuary, the experiment described above was repeated with similar results. After 4 weeks of bubbling with the mixture of $\mathrm{H}_{2}$ and $\mathrm{CO}_{2}$, the $\mathrm{pH}$ of the medium was 5.0. Results of a gas-chromatographic analysis of the medium indicated that a single product, acetic acid, was produced in a concentration which reached $0.06 \mathrm{M}$. Microscopic examination of the growth liquor revealed a dominant population of oval-shaped, highly motile cells frequently occurring in pairs.

When enrichment cultures were attempted in a closed system, growth of methanogenic organisms interfered with the isolation of the acetogenic bacteria. One of us (R.T.) devised a selective medium in which the addition of sodium dithionite inhibited the growth of methanogenic bacteria. Methanobacterium ruminantium strain M-1, for example, was inhibited at a concentration of $5 \mathrm{mg} / 100 \mathrm{ml}$ of medium, whereas the acetogenic bacteria were resistant to concentrations as high as $40 \mathrm{mg} / 100 \mathrm{ml}$. A successful enrichment was obtained by placing a $5-\mathrm{ml} \mathrm{sam}$ ple of black sediment in a 100-ml serum bottle, which was then sealed and flushed with hydrogen. A 5-ml amount of medium M1 which con- 
tained $1 \mathrm{mg}$ of sodium dithionite was injected into the sealed bottle. By use of techniques recently described (2), an atmosphere of $\mathrm{H}_{2}-\mathrm{CO}_{2}$ (67:33) was placed in the bottle to a final pressure of $1.7 \mathrm{~atm}$. Each bottle was incubated at $30^{\circ} \mathrm{C}$ without shaking, since for unknown reasons agitation of the culture inhibited growth. Each culture bottle was repressurized every 3 days until the production of acetic acid reached the $100 \mathrm{mM}$ level.

Isolation of bacteria. A sample from a successful enrichment culture, which had been inoculated with sediment from a marine estuary, was streaked on medium $\mathrm{M} 2$, and plates were incubated at $30^{\circ} \mathrm{C}$ as previously described (2). Acetogenic colonies were distinguished by a clearing of the $\mathrm{CaCO}_{3}$ in the vicinity of each colony (Fig. 1). Circular, convex colonies were usually visible after a few days and reached a diameter of $1 \mathrm{~mm}$ in 7 to 10 days. Older colonies showed a slight yellow pigmentation; however, no fluorescence was observed under ultraviolet light either under anaerobic or aerobic condi- tions. When tested, the colonies did not give a positive catalase reaction. The organism (designated strain WB1) proved to be a strict anaerobe, and it was cloned, maintained in stock culture, and subcultured by a modification of the Hungate technique (2). Colonies were composed of nonsporeforming, motile, oval-shaped rods which frequently occurred in pairs. The rods measured about $1 \mu \mathrm{m}$ in width and about $2 \mu \mathrm{m}$ in length and contained a single, long, subterminal flagellum and fine pili-like structures (Fig. 2B). Rarely, cells with two subterminal flagella were also observed. A study by Mayer and Schoberth on the ultrastructure of this organism is being published elsewhere (manuscript in preparation).

Substrates utilized for growth. Evidence presented in Table 1 indicates that the acetogenic organism (strain WB1) can oxidize substrates other than hydrogen but that the substrate range is rather narrow, being limited to fructose, glucose, lactate, glycerate, and formate. The only major product detected was acetate;

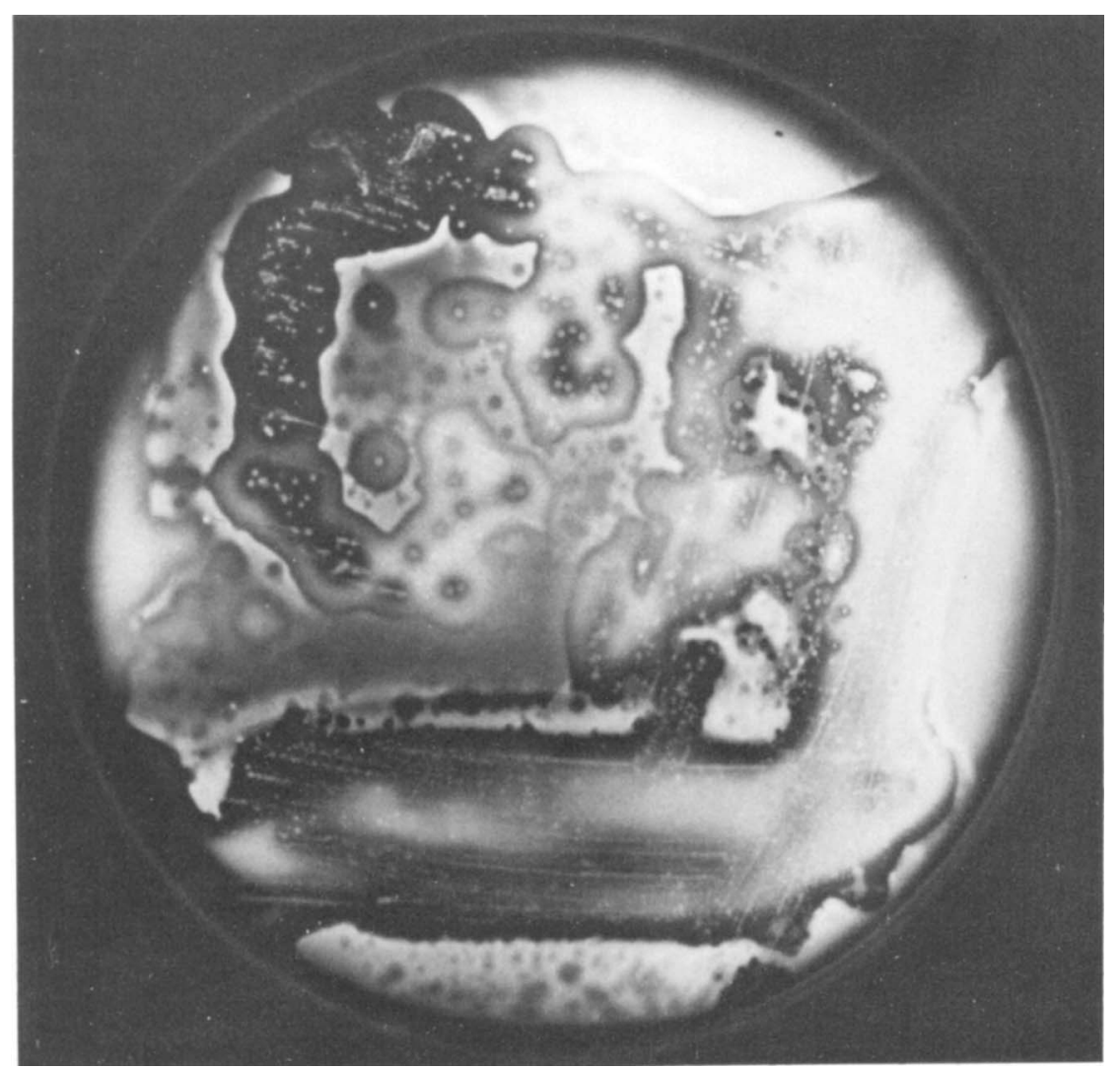

FIG. 1. Colonies of Acetobacterium woodii which were grown in an atmosphere of $\mathrm{H}_{2}: \mathrm{CO}_{2}(80: 20)$ on a medium which contained $\mathrm{CaCO}_{3}$. Acetogenic colonies are surrounded by clear zones. Magnification, $\times 1.2$. 

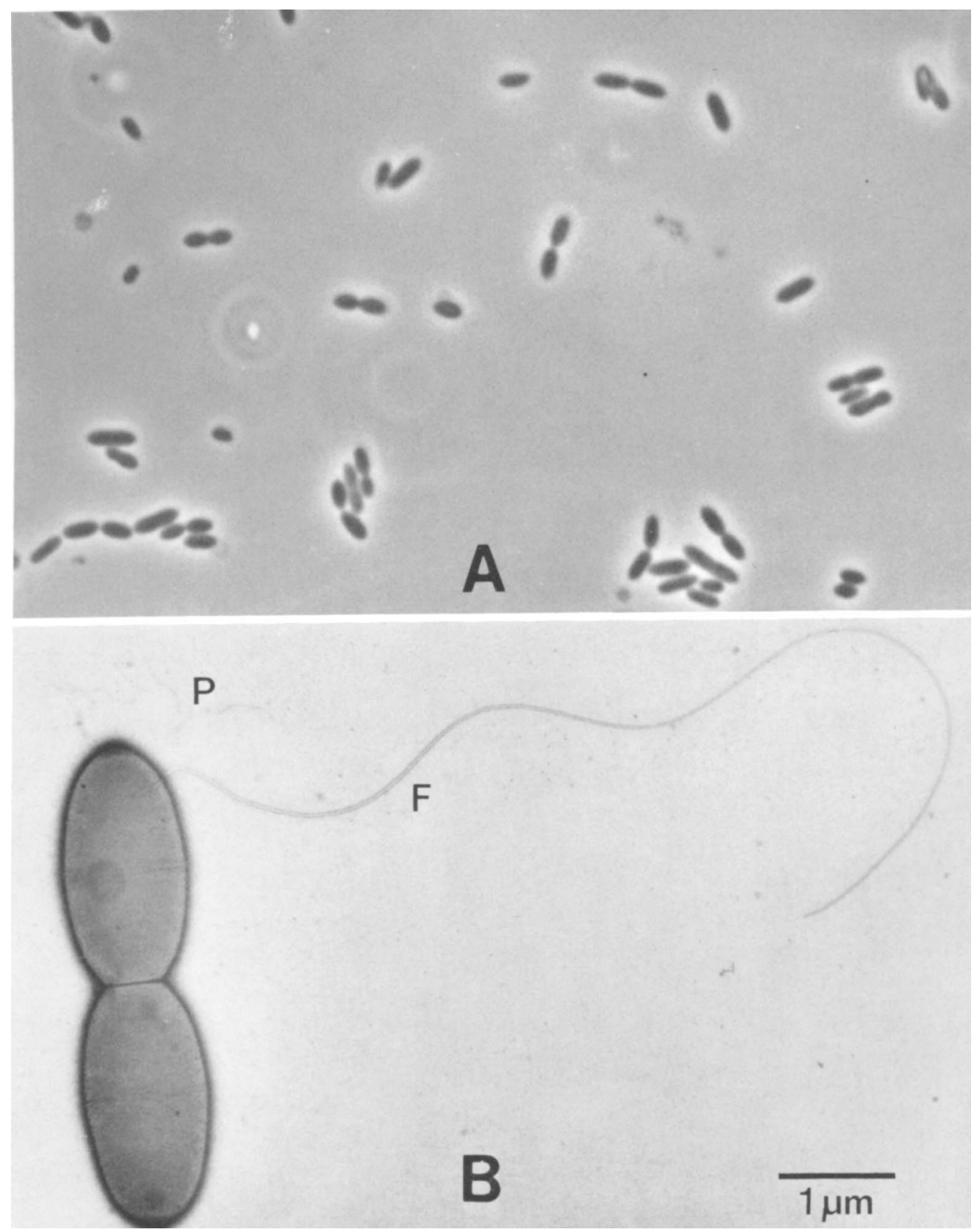

FIG. 2. (A) Phase-contrast photomicrograph of living cells of the acetogenic bacterium. Magnification, $\times 2,000$. (B) Electron micrograph of the acetogenic bacterium showing a single, subterminal flagellum, $F$, and pili-like structures, $P$. The micrograph was taken by $F$. Mayer.

traces of a compound which may have been succinate were detected when substrates other than hydrogen were utilized. The results presented in Fig. 3 show that the acetogenic organism produced a homoacetic fermentation: 92 to $95 \%$ of the fructose was converted to acetate. The generation time of the organism at $30^{\circ} \mathrm{C}$ was $6 \mathrm{~h}$. However, no evidence was obtained for the formation of hydrogen during the fermentation. The fermentor was continuously sparged 
with nitrogen at a flow rate of $15 \mathrm{~cm}^{3} /$ min per liter of medium, and the theoretical amount of acetate was nearly formed from the fructose used, indicating that molecular hydrogen likely was not formed since a significant portion would have equilibrated with the medium and would have been scrubbed out with the nitrogen. Growth with $\mathrm{H}_{2}-\mathrm{CO}_{2}$ was much slower. In these experiments, the cell yield on the fermented fructose was $2.2 \mathrm{~g}$ (wet weight) per liter of medium, and the yield on the gas mixture was 1.5.

Nutrition. The results of the nutrition studies (Table 2) indicate that pantothenate alone can replace the vitamin requirement for strain WB1. In this experiment, the growth yield was low; to avoid introducing variables, acetic acid was not neutralized, and the gas atmosphere was not replaced. The organism could be subcultured continually in media which contained calcium pantothenate as the only vitamin.

Stoichiometry of growth on $\mathrm{H}_{2}$ and $\mathrm{CO}_{2}$. To determine the amount of hydrogen and carbon dioxide consumed as well as the amount of acetic acid formed by strain WB1, growth was followed in sealed tubes as described in Materials and Methods. Gas consumption and acetate

TABLE 1. Organic substrates tested for support of growth of the acetogenic bacterium under an atmosphere of nitrogen and carbon dioxide (80:20)

\begin{tabular}{|c|c|}
\hline Organic substrate tested & $\begin{array}{l}\text { Final absorbance } \\
\text { of broth culture } \\
\text { (at } 660 \mathrm{~nm} \text { ) }\end{array}$ \\
\hline Fructose $\mathrm{e}^{h}$ & 1.12 \\
\hline Glucose $^{h}$ & 0.89 \\
\hline DL-Lactate $(\text { sodium })^{b}$ & 0.50 \\
\hline DL-Glycerate (sodium) ${ }^{b}$ & 0.35 \\
\hline Formate (sodium) ${ }^{c}$ & 0.40 \\
\hline Other compounds ${ }^{d}$ & $<0.10$ \\
\hline
\end{tabular}

${ }^{a}$ The inoculated basal medium (without added substrate) supported growth which reached an absorbance $<0.1$.

${ }^{b}$ This substrate supported the growth of the acetogenic bacterium.

Cells initially grew poorly on formate, but by continual subculture on this substrate, an absorbance of 0.4 was obtained at $100 \mathrm{mM}$ formate.

${ }^{d}$ Compounds tested which did not serve as substrates for the growth of the acetogenic bacterium: methanol, ethanol, $n$-propanol, $i$-propanol, $n$-butanol, $i$-butanol, sec-butanol, and $n$-pentanol; acetic, propionic, butyric, valeric, fumaric, L-malic, pyruvic, and succinic acids; alanine, aspartic acid, Casamino Acids, casein hydrolysate, glutamic acid, glycine, and serine; arabinose, cellobiose, cellulose, 2-deoxyglucose, galactose, lactose, mannose, maltose, melezitose, pectin, raffinose, rhamnose, ribose, starch, sucrose, trehalose, xylose, mannitol, inositol, glycerol, alginic acid, galactonolactone, galacturonic acid, gluconolactone, and glucuronic acid.

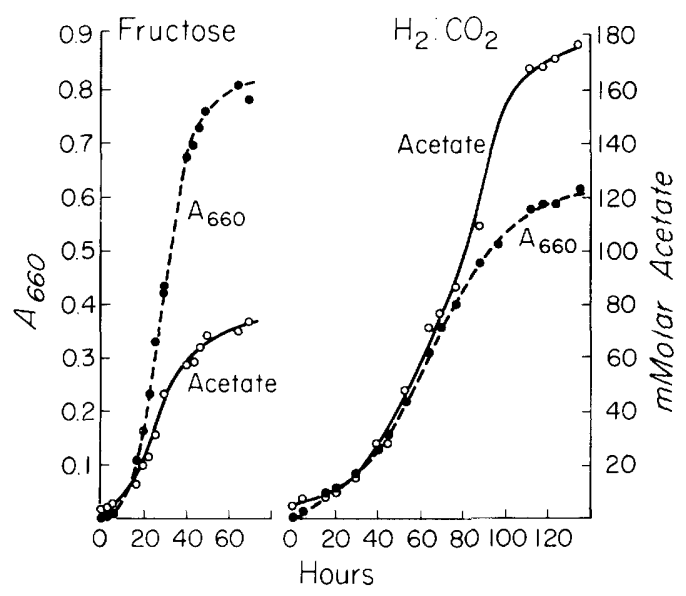

FIG. 3. Growth of and production of acetic acid by the acetogenic bacterium in fermentor cultures. Oxygen-free nitrogen was bubbled $\left(15 \mathrm{~cm}^{3} / \mathrm{min}\right.$ per liter of medium) through the culture in which fructose was the substrate, and an oxygen-free mixture of $\mathrm{H}_{2}$ $\mathrm{CO}_{2}$ (80:20) was bubbled $\left(40 \mathrm{~cm}^{3} / \mathrm{min}\right.$ per liter of medium) through the fermentor from which the data plotted on the right were obtained. Absorbance of samples was determined by use of a 1 -cm light path.

formation correlated with an increase in the absorbancy of the culture (Fig. 4). During growth, $6 \mu \mathrm{mol}$ of gas was consumed per $\mu \mathrm{mol}$ of acetate produced. The results of analyses by gas chromatography agreed with equation 1 . No growth occurred in tubes where $\mathrm{N}_{2}$ was substituted for $\mathrm{H}_{2}$.

Additional characteristics of the acetogenic bacterium. Batches of cells for use in the determination of the $\mathrm{G}+\mathrm{C}$ content of the DNA were grown on fructose as well as on $\mathrm{H}_{2-}$ $\mathrm{CO}_{2}$. The buoyant density of purified DNA from cells cultured under either condition was 1.699 $\mathrm{g} / \mathrm{cm}^{3}$, and the calculated $\mathrm{G}+\mathrm{C}$ content was 39 mol\%. To document further the characteristics of the organism, cultures were sent to the Anaerobe Laboratory, Virginia Polytechnic Institute (VPI) and State University, Blacksburg, $\mathrm{Va}$. The results of a series of standard substrate fermentations and reaction tests confirmed our results and indicated that the organism was unlike any of the bacteria in the VPI culture collection (L. V. Holdeman, personal communication).

Additional strains of the acetogenic organism, which are designated RT1 and RT2, also were studied; characteristics of these strains closely resembled those of strain WB1.

\section{DISCUSSION}

Although the acetogenic bacterium is unique in its ability to grow by the oxidation of hydro- 
gen and reduction of carbon dioxide to acetic acid, it appears from preliminary studies that the homoacetic fermentation of sugar closely resembles the fermentations carried out by strains of C. thermoaceticum and C. formicoaceticum $(1,11)$.

We propose the establishment of a new genus, Acetobacterium (A - ce to t bac $\cdot$ te'rium. L.n. acetum vinegar; Gr.neut.n. bakterion a small rod; M.L. neut.n. Acetobacterium vinegar rod) for these acetogenic bacteria. The type species of this genus is Acetobacterium woodii sp. nov. (wood'i $\cdot \mathbf{i} \cdot$ M.L. gen.n. woodii of Wood, named for Harland G. Wood, who pioneered studies on the total synthesis of acetate from $\mathrm{CO}_{2}$ by bacteria). Until definitive evidence becomes available, we suggest that Acetobacterium be placed in the family Propionibacteriaceae. Strains of Acetobacterium woodii appear to be most closely related to the genus Eubacterium, but they differ in their ability to grow by the anaerobic oxidation of hydrogen and the reduction of $\mathrm{CO}_{2}$ to acetic acid as well as in their ability to carry out only homoacetic fermentations from reduced substrates. A combined generic and specific description follows.

Acetobacterium gen. nov. and Acetobacterium woodii sp. nov.

Morphology. Oval-shaped, short rods measuring 1.0 by $2.0 \mu \mathrm{m}$. Cells frequently occur in pairs. Gram positive. Highly motile by means of one or two subterminal flagella. Endospores are absent.

Colony characteristics. Colonies are circular and convex and grow to a diameter of $1 \mathrm{~mm}$

TABLE 2. Vitamin requirements of the acetogenic bacterium when grown in a mineral medium under a pressurized atmosphere of hydrogen and carbon dioxide (67:33)

\begin{tabular}{lcc}
\hline $\begin{array}{c}\text { Vitamins added to basal mineral } \\
\text { medium }\end{array}$ & $\begin{array}{c}\text { Amount of } \\
\text { vitamin } \\
\text { added per } \\
\text { liter of me- } \\
\text { dium }(\mu \mathrm{g})\end{array}$ & $\begin{array}{c}\text { Final ab- } \\
\text { sorbance of } \\
\text { broth cul- } \\
\text { ture }\end{array}$ \\
$660 \mathrm{~nm})$
\end{tabular}

${ }^{a}$ Absorbance values, when compared to the blank $(0.04)$, indicate a negligible stimulation of growth by addition of vitamins other than pantothenate.

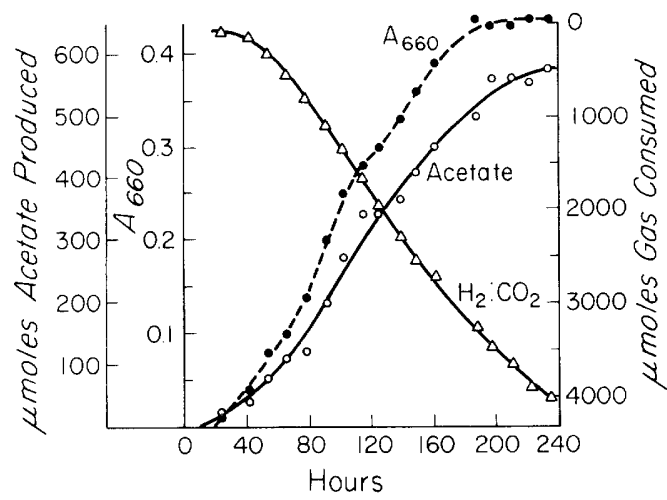

FIG. 4. Growth and stoichiometry of substrate utilization and acetic acid production by the acetogenic bacterium in a closed, pressurized system.

in 7 to 10 days. Older colonies may show a slight yellow pigmentation. Traces of a water-soluble yellow pigment may be excreted into the medium. Catalase negative.

DNA base composition. $39 \mathrm{~mol} \% \mathrm{G}+\mathrm{C}$.

Temperature for optimal growth. $30^{\circ} \mathrm{C}$.

pH relationships. Remains viable at $\mathbf{p H} 5$ for many weeks.

Physiology. Obligately anaerobic. Ferments $1 \mathrm{~mol}$ of fructose to $3 \mathrm{~mol}$ of acetate; also produces homoacetic fermentations from glucose, lactate, and glycerate. May be adapted to ferment formate. Oxidizes hydrogen and reduces carbon dioxide according to the following equation: $4 \mathrm{H}_{2}+2 \mathrm{CO}_{2} \rightarrow \mathrm{CH}_{3} \mathrm{COOH}+2 \mathrm{H}_{2} \mathrm{O}$. Traces of succinate may be produced from organic substrates.

Nutrition. Grows in a defined mineral medium with the addition of substrates $\left(\mathrm{H}_{2}-\mathrm{CO}_{2}\right.$ or organic substrate). Pantothenate is required.

Source. Marine and fresh-water black sediments.

Type strain. WB1. This strain, isolated from a marine estuary, has been deposited in the American Type Culture Collection (ATCC), Rockville, Md., under the number 29683 and in the German Collection of Microorganisms (DSM), Göttingen, FRG, under the number 1030.

\section{ACKNOWLEDGMENTS}

We thank L. V. Holdeman and the VPI Anaerobe Laboratory for examining a culture of Acetobacterium woodii. DNA purified from Micrococcus luteus was a gift from C. L. Hershberger. We thank A. M. Walfield for assistance in density gradient centrifugation and F. Mayer, Göttingen, for providing the electron micrograph. S. Schoberth was the recipient of a fellowship from the Deutsche Forschungsgemeinschaft, and R. S. Tanner is the recipient of a predoctoral fellowship from the National Science Foundation. This work was supported by National Science Foundation grant PCM 76-02652. 


\section{REPRINT REQUESTS}

Address reprint requests to: Dr. R. S. Wolfe, Department of Microbiology, 131 Burrill Hall, University of Illinois, Urbana, IL 61801.

\section{LITERATURE CITED}

1. Andreesen, J. R., G. Gottschalk, and H. G. Schlegel. 1970. Clostridium formicoaceticum nov. spec. isolation, description and distinction from C. aceticum and $C$. thermoaceticum. Arch. Mikrobiol. 72:154-174.

2. Balch, W. E., and R. S. Wolfe. 1976. A new approach to the cultivation of methanogenic bacteria: 2-mercaptoethanesulfonic acid (HS-CoM)-dependent growth of Methanobacterium ruminantium in a pressurized atmosphere. Appl. Environ. Microbiol. 32:781-791.

3. Bryant, M. P., B. C. McBride, and R. S. Wolfe. 1968. Hydrogen-oxidizing methane bacteria. I. Cultivation and methanogenesis. J. Bacteriol. 95:1118-1123.

4. Decker, V. K., K. Jungermann, and R. K. Thauer. 1970. Energy production in anaerobic organisms. Angew. Chem. Int. Ed. Engl. 9:138-158.

5. Fontaine, F. E., W. H. Peterson, E. McCoy, M. J. Johnson, and G. J. Ritter. 1942. A new type of glucose fermentation by Clostridium thermoaceticum n. sp. J. Bacteriol. 43:701-715.

6. Fischer, F., R. Lieske, and K. Winzer. 1932. Biologische Gasreaktionen. II. Mitteilung: Über die Bildung von Essigsäure bei der biologischen Umsetzung von Kohlenoxyd und Kohlensäure mit Wasserstoff zu Methan. Biochem. Z. 245:2-12.

7. Karlsson, J. L., B. E. Volcani, and H. A. Barker. 1948. The nutritional requirements of Clostridium ace ticum. J. Bacteriol. 56:781-782.

8. Ljungdahl, L. G., and H. G. Wood. 1969. Total synthesis of acetate from $\mathrm{CO}_{2}$ by heterotrophic bacteria. Annu. Rev. Microbiol. 23:515-535.
9. Marmur, J. 1961. A procedure for the isolation of deoxyribonucleic acid from microorganisms. J. Mol. Biol. 3:208-218.

10. Nelson, N. 1944. A photometric adaptation of the Somogyi method for the determination of glucose. J. Biol. Chem. 153:375-380.

11. O'Brien, W. E., and L. G. Lungdahl. 1972. Fermenta tion of fructose and synthesis of acetate from carbon dioxide by Clostridium formicoaceticum. J. Bacteriol. 109:626-632.

12. Rose, I. A., M. Grunberg-Manago, S. R. Korey, and S. Ochoa. 1954. Enzymatic phosphorylation of acetate. J. Biol. Chem. 211:737-756.

13. Schildkraudt, C. L., J. Marmur, and P. Doty. 1962. Determination of the base composition of deoxyribonucleic acid from its buoyant density in $\mathrm{CsCl}$. J. Mol. Biol. 4:430-443.

14. Schulman, M., R. K. Ghambeer, L. G. Ljungdahl, and H. G. Wood. 1973. Total synthesis of acetate from $\mathrm{CO}_{2}$. VII. Evidence with Clostridium thermoaceticum that the carboxyl of acetate is derived from the carboxyl of pyruvate by transcarboxylation and not by fixation of $\mathrm{CO}_{2}$. J. Biol. Chem. 248:6255-6261

15. Schulman, M., D. Parker, L. G. Ljungdahl, and $\mathbf{H}$. G. Wood. 1972. Total synthesis of acetate from $\mathrm{CO}_{2}$. $\mathrm{V}$. Determination by mass analysis of the different types of acetate formed from ${ }^{1:} \mathrm{CO}_{2}$ by heterotrophic bacteria. J. Bacteriol. 109:633-644.

16. Wieringa, K. T. 1936. Over het verdwijnen van waterstof en koolzuur onder anaerobe voorwarden. Antonie van Leeuwenhoek J. Microbiol. Serol. 3:263-273.

17. Wieringa, K. T. 1940 . The formation of acetic acid from carbon dioxide and hydrogen by anaerobic spore-forming bacteria. Antonie van Leeuwenhoek J. Microbiol. Serol. 6:251-262.

18. Wolin, E. A., M. J. Wolin, and R. S. Wolfe. 1963 Formation of methane by bacterial extracts. J. Biol. Chem. 238:2882-2886. 